\title{
Dampak Psikologis Pengalaman Kerentanan yang Dialami Perempuan Purna Pekerja Migran Indonesia: Studi Kasus pada Kantong Buruh Migran di Kota Makassar
}

\author{
Nur Ismi Ramadani ${ }^{1}$ \\ ${ }^{1}$ Sekolah Pascasarjana Universitas Hasanuddin \\ Email: nurismiramadhani68@gmail.com
}

\begin{tabular}{llll}
\hline Submitted & $:$ October, $30^{\text {th }}, 2020$ & Revision & $:$ June, $28^{\text {th }}, 2021$ \\
Reviewed & $:$ January, $3^{\text {th }}, 2021$ & Published & $:$ June, $18^{\text {th }}, 2021$ \\
\hline
\end{tabular}

Abstract: This study aims to describe the psychological Impact of vulnerability experiences experienced by retired Indonesian migrant workers who experience vulnerability from unpleasant treatment during the migration process. This research is a case study with a descriptive qualitative research approach and uses data collection methods, namely in-depth interviews and observations. The subjects of this studu were three women who live in Bangkala Village, Manggala District, Makassar city, who have backgrounds as former women migrant workers. The results of the data analysis show that the subject experiences various psychological dynamic conditions that greatly impact the vulnerability experienced during his tenure as migrant workers in the oil palm plantation sector. Such as trauma, emotional disturbances and anxiety disorder with different psychological coping strategies depending on the specific situation experienced by each subject.

Keywords: Psychological Impact, vulnerability experiences, Women, Migrant Workers

Abstrak: Penelitian ini bertujuan untuk menggambarkan Dampak Psikologis Pengalaman Kerentanan yang dialami Perempuan Purna Pekerja Migran Indonesia yang mengalami pengalaman kerentanan dari perlakuan yang tidak menyenangkan selama proses migrasi. Penelitian ini adalah sebuah studi kasus dengan pendekatan penelitian kualitatif deskriptif dan menggunakan metode pengumpulan data yaitu wawancara mendalam dan observasi. Subjek penelitian ini berjumlah tiga perempuan yang berdomisili di Kelurahan Bangkala Kecamatan Manggala Kota Makassar yang memiliki latar belakang sebagai perempuan purna pekerja migran. Hasil analisis data menunjukkan bahwa subjek mengalami berbagai kondisi dinamika psikologis yang sangat berdampak dari situasi kerentanan yang dialami selama masa kerja 
sebagai buruh migran di sektor perkebunan sawit. seperti trauma, gangguan emosi dan gangguan kecemasan yang sama dengan strategi penanganan psikologis yang berbeda bergantung situasi tertentu yang dialami masing-masing subjek.

Kata Kunci: Dampak Psikologis, Pengalaman Kerentanan, Perempuan, Pekerja Migran

\section{Pendahuluan}

Pekerja Migran menjadi salah satu penyumbang utama pertumbuhan ekonomi Negara. Faktor yang menjadi fenomena migrasi adalah kondisi ekonomi sosial dan perbedaan demografis di Asia Tenggara. Pekerja migran asal Indonesia biasanya bekerja dengan tingkat pendidikan dan keterampilan rendah serta umumnya adalah perempuan. Banyak dari mereka yang memutuskan untuk bekerja di luar negeri dengan kemampuan/keahlian yang minim dan akhirnya hanya bisa ditempatkan sebagai pekerja di sektor domestik atau pekerja rumah tangga, bahkan melalui proses migrasi yang tidak aman.

Malaysia adalah Negara tujuan utama pekerja migran Indonesia dari tahun 2017-2019 (BNP2TKI, 2020) Masalah migrasi yang paling banyak dialami oleh perempuan, Perempuan seringkali menjadi korban dari ketidakadilan dan ketidaksetaraan gender dalam pembangunan disemua aspek kehidupan, Sosial budaya, lingkungan, pendidikan, maupun perekonomian sehingga perempuan menjadi rentan untuk mengalami kekerasan. Keadilan dan kesetaraan menjadi gagasan dasar, tujuan untuk mencapai kesejahteraan, terwujudnya keadilan dan kesetaraan gender ditandai tidak adanya diskriminasi jender. Namun faktanya, hingga hari ini masih terus terjadi dilihat dari data catahu 2020 komisi nasional anti kekerasan terhadap perempuan (Komnas Perempuan) bahwa sepanjang tahun 2019 yang dilaporkan dan tangani sebanyak 431.471 kasus kekerasan terhadap perempuan di Indonesia (Catahu Komas Perempuan 2020).

Pentingnya memberikan perlindungan hukum kepada pekerja migran perempuan adalah jaminan perlindungan keamanan terhadap semua bentuk kekerasan fisik atau psikologis, seperti pelecehan, pemerkosaan, penyiksaan, penganiayaan, pembunuhan dan pengusiran. Perlindungan ini bertujuan untuk menghindari kesewenang-wenangan tindakan individu atau kelompok dan negara. Perlindungan hukum berarti ada dua pihak terkait, di mana ada orang yang harus dilindungi dari tindakan sewenang-wenang dan pihak-pihak yang harus 
memberikan perlindungan. Perlindungan hukum adalah perlindungan terhadap martabat yang melekat dan pengakuan hak asasi manusia kepada setiap orang di negara tertentu untuk menghindari kesewenang-wenangan.

Undang-Undang Nomor 18 Tahun 2017 tentang Pelindungan Pekerja Migran Indonesia (PPMI) memuat pelindungan hak-hak PMI dan keluarga yang cukup komprehensif dari segi perlindungan hukum, sosial, dan ekonomi. Pelindungan terhadap hak-hak ini melingkupi seluruh tahapan migrasi sejak sebelum bekerja, masa bekerja, hingga setelah bekerja. Dibutuhkan pengawasan dan penegakan hukum yang tegas untuk perlindungan PMI di setiap tahap migrasi, meliputi sanksi administratif dan pidana. UU Nomor 18 Tahun 2017 memandatkan RPP turunan dari UU tersebut dibentuk paling lama dua tahun sejak UU disahkan, dengan kata lain, tahun 2019. Namun hingga saat ini amanat tersebut belum dilaksanakan ditataran pemerintah daerah.

Data pengaduan yang diterima Unit Pelayanan dan Rujukan (UPR) Komnas Perempuan dari 2018 hingga November 2019 menunjukkan meskipun Indonesia sudah dua tahun mengesahkan UU PPMI, pola pelanggaran dalam konteks migrasi dan kekerasan terhadap pekerja migran perempuan yang terjadi sejak 30 tahun lalu masih terjadi dan berulang. Kekerasan fisik, psikis dan seksual (termasuk pelecehan seksual, pemerkosaan, pemaksaan pelacuran), jeratan hutang, ancaman dan pemerasan, pelanggaran hak atas informasi, manupulasi dokumen, perampasan dokumen, menjadi overstay karena dokumen tidak diurus oleh pemberi kerja, pelanggaran kontrak kerja, dipekerjakan pada beberapa pemberi kerja, dipaksa bekerja tak kenal waktu, beban kerja yang berlebihan, dilarang beribadah, dilarang berkomunikasi dengan keluarga di Indonesia hingga dilarang kembali ke tanah air.

Kebijakan migrasi tenaga kerja yang sangat ketat dinegara tujuan dan redahnya komitmen pemerintah dari kedua Negara pengirim dan tujuan untuk memberikan perlindungan terhadap migran meng-akibatkan rentannya kelompok pekerja yang memerlukan perlindungan khusus. Perlindungan ini mencakup, namun tidak terbatas, tenaga kerja illegal dan korban perdagangan orang. Jaminan sosial di Malaysia tidak sepenuhnya memper-timbangkan pengalaman dan perspektif perempuan, dimana perempuan pekerja migran indonesia sangat kritis dalam isu ini. Lebih lanjut, pengaturan migrasi di kedua negara, Indonesia dan Malaysia, juga masih ditemukan banyak masalah (Maulidia, 2019).

Persepsi pekerja migran yang menganggap bahwa kesempatan bekerja diluar negeri jauh lebih terbuka menjadi faktor meningkatnya kasus dan mengakibatkan 
para pekerja migran tetap berangkat walaupun dengan keterampilan yang terbatas bahkan dengan prosedur yang tidak aman. Perlakuan tidak menyenangkan yang sering dialami oleh pekerja migran selama berada diluar negeri yaitu penyiksaan yang merupakan perlakuan yang secara sengaja dilakukan untuk melukai perasaan orang lain baik secara fisik, psikis, sosial, seksual, verbal dan ekonomi.

Pekerja Migran Indonesia (PMI) yang melakukan migrasi ke negara penempatan memiliki potensi terkena gangguan kesehatan mental dan psikologis. Sejumlah pekerja migran terkena gangguan psikologis ketika berada di negara penempatan. Lingkungan sosial baru seperti budaya, agama serta adat istiadat yang berbeda menjadi salah satu penyebab terjadinya gangguan kesehatan mental dan psikologis. Selain itu, kondisi pekerjaan yang penuh tekanan dari majikan membuat pekerja migran rentan terkena gangguan kesehatan mental dan psikologis.

Berbagai stressor yang terjadi pada lingkungan kerja atau lingkungan seharihari akan menjadi hal yang sulit apabila pekerja migran tidak dapat beradaptasi dengan baik. Penelitian-penelitian terdahulu banyak meng-ungkapkan mengenai faktor pendukung dan dampak dari strategi penanganan yang dirasakan oleh korban trafficking. Herdiana \& Suryanto (2019) menjelaskan bahwa penyintas menerima dampak fisik, psikologis, dan sosial. Pengalaman yang menjadi catatan penting, berupa penganiayaan yang me-nimbulkan luka fisik, perasaan-perasaan negatif, dan tindakan-tindakan sosial yang tidak terkendali seperti menarik diri dari orang lain. untuk menangani keadaan yang sulit seperti itu, biasanya dukungan yang diterima korban lebih banyak datang dari yayasan yang menjadi rumah aman bagi korban. Korban mendapatkan perlindungan, pemulihan fisik dan psikis dan akses kesehatan yang cukup memadai. Selain itu, bagi korban yang tetap tinggal bersama keluarga, dukungan lebih banyak diterima dari keluarga besar dan anggota keluarga yang tidak terlibat dalam kasus tersebut. Sekecil apapun bantuan yang diterima oleh korban, ternyata membuat korban merasa mendapatkan perlindungan dan memberikan rasa aman.

Awaliyah M. Suwetty, Asti Melani Astari, Titin Andri Wihastuti (2019) mengenai Mental Health of Human Trafficking: A Systematic Review men-jelaskan bahwa perdagangan manusia menjadi kejahatan global di seluruh dunia. Praktek perdagangan manusia dalam bentuk eksploitasi manusia yang berimplikasi pada pelanggaran HAM. Korban per-dagangan manusia akan mengalami masalah kesehatan baik fisik maupun masalah mental. Penelitian tersebut mengidentifikasi dan merangkum masalah kesehatan mental para korban perdagangan orang dan 
menunjukkan insiden perdagang-an manusia sangat mempengaruhi kesehatan mental korban. Korban mengalami kecemasan, depresi, isolasi, disorientasi, agresi, bunuh diri ideasi, defisit perhatian, gangguan psikotik, stres perilaku dan pascatrauma gangguan (PTSD). Untuk penelitian lebih lanjut diperlukan upaya dalam mengatasi mental dampak kesehatan dari korban perdagangan manusia. Fokus pada upaya pencegahan adalah melalui kampanye pemerintah, IOM dan penegakan hukum dan juga pemenuhannya tentang hak-hak per-dagangan manusia.

Bhugra (2004) mengenai Migration and mental health menjelaskan bahwa Migrasi dan stresor yang menyertainya memengaruhi individu yang bermigrasi dan keluarga mereka. Tujuan dari penelitian ini adalah untuk menyaring informasi yang ada tentang bagaimana migrasi memengaruhi kondisi mental individu dan bagaimana hal itu menentukan mencari jalur untuk bantuan pelayanan. Hasil penelitian ini mem-berikan latar belakang tentang tipologi migrasi, dampaknya terhadap masya-rakat dan juga individu. Selanjutnya, hubungan penyakit mental dengan migrasi dieksplorasi dan dijelaskan. Dianjurkan rencana penelitian dimasa depan dapat berhubungan dengan temuan ini. Kesimpulan penelitian ini yaitu migrasi bisa menjadi fenomena yang sangat menimbulkan stres. Namun tidak semua migran mengalami proses yang sama. Ahli klinis perlu menyadari strategi koping serta ketahanan di antara migran.

\section{Dinamika Psikologis Perempuan Pekerja Migran}

Saptoto mendefenisikan dinamika psiko-logis sebagai keterkaitan antara berbagai aspek psikologis yang ada dalam diri seseorang dengan faktor-faktor dari luar yang mempengaruhinya. Fathurrochman dan Djalaludin Ancok menggunakan istilah dinamika psikologis untuk menjelaskan secara lebih lanjut hubungan prosedur objektif dengan penilaian keadilan. Sedangkan menurut Halloway, dkk istilah dinamika psikologis digunakan untuk menerangkan keter-kaitan berbagai aspek psikologis yang ada dalam diri responden dalam hubungannya dengan kondisi masya-rakat. Selanjutnya Widiasari (2009) mengatakan bahwa dinamika psikologis merupakan aspek motivasi dan dorongan yang bersumber dari dalam maupun luar individu, yang mempengaruhi mental serta membantu individu menyesuaikan diri dengan keadaan dan perubahan. Lebih lanjut, Chaplin mengatakan bahwa dinamika psikologis merupakan sebuah sistem psikologi yang menekankan penelitian terhadap hubungan sebab akibat dalam motif dan dorongan hingga munculnya sebuah perilaku. 
Carta et al (2005) mengemukakan bahwa migrasi adalah proses yang sangat kompleks dimana orangyang berimigrasi kemungkinan akan menghadapi perubahan seperti peristiwa kehidupan mulai dari kelaparan, situasi hubungan antar keluarga dan lingkungan sosial, bahasa dan budaya. Bhugra \& Gupta (2011) menjelaskan mengenai perubahan-perubahan tersebut disertai dengan pengalaman pascamigrasi. seperti kesulitan dalam mencari pekerjaan, tempat tinggal, mempelajari norma-norma dan budaya di sejumlah masyarakat dan mengembangkan hubungan sosial. yang kesemuanya mungkin memberi tekanan besar bagi migran. Migran mengalami perubahan dan perlu beradaptasi dengan perubahan itu pada tingkat yang berbeda yang dapat bervariasi dalam ruang dan waktu. Walaupun benar bahwa penyakit mental disebabkan oleh banyak faktor dan tidak dapat dipersempit menjadi satu faktor, penting juga bahwa faktor-faktor psikososial memainkan peran penting dalam mempercepat timbulnya penyakit mental.

Migrasi telah dianggap memiliki dampak substansial pada kesehatan mental masyarakat, baik sebagai faktor pemicu atau sebagai faktor yang memberatkan. setiap tahap migrasi dapat melibatkan faktor-faktor risiko tertentu untuk kesehatan mental, termasuk kepribadian individu dan pengalaman traumatis (seperti kekerasan dan perang selama pra-migrasi) lamanya masa tunggu, penurunan kelelahan, jenis trauma selama proses migrasi, kesulitan sosial, diskriminasi ras. kondisi kehidupan dan status hukum pasca migrasi.

Marrie Wattie (2002) dalam (Sukamdi, 2007) menjelaskan bahwa berbagai istilah yang seringkali dilekatkan seperti pahlawan devisa, ekspor tenaga kerja dan lain sebagainya memperlihatkan fenomena migrasi internasional secara sempit dipandang sebagai pengiriman barang dan menghasilkan uang sebagaimana ekspor impor barang. Bahkan memahami motif bermigrasi pun dari sisi ekonomi tidak harus dilakukan dengan menggunakan konsep cash income secara sempit. Dengan menempatkan motif ekonomi sebagai fokus, ada kecenderungan untuk meremehkan migran sebagai individu, sebagai manusia dan hubun gan sosial psikologis dengan individu lain serta lingkungan sosialnya.

Persoalan patriarki juga masih menjadi bagian yang lekat dimasyarakat ini. Hal ini tampak pada fenomena feminisasi kerja yang hampir tak terhindarkan. Peluang perempuan untuk berpartisipasi diranah kerja sama halnya dengan nagara dunia ketiga lainnya memang telah diberikan. Mereka diberikan peluang untuk juga menjadi tenaga kerja yang berpenghasilan. Sehingga dalam perjuangan mencapai kesejahteraan, perempuan tidak jauh berbeda dengan laki-laki. Namun 
kultur patriarki yang begitu dalam terinternalisasi sama sekali tidak memberikan kebebasan bagi perempuan. Mereka diterima sebagai pekerja, namun tetap saja ditempatkan diwilayah-wilayah yang merepresentasi-kan aktivitas domestic.

Buruh perempuan hanya diberikan kepercayaan untuk mengerjakan hal-hal yang membutuhkan keterampilan, kehati-hatian dan ketelatenan pekerjaan yang membutuhkan kemampuan untuk mengambil keputusan memimpin dan kompetitif tetap diidentikkan dengan pekerja laki-laki. Laki-laki masih dianggap sebagai subjek yang memimpin, mendominasi dan menentukan. Maka, sejauh apapun perempuan melibatkan dirinya diranah kerja, mereka tetap memiliki keterbatasan untuk mendapat-kan pengembangan karir. Sehingga banyaknya tenaga kerja perempuan yang berpartisipasi diranah public hanya akan menjadi buruh upahan yang terus beresiko untuk didiskriminasi dan diekspoitasi.

Fenomena migrasi di Indonesia lahir dari pemiskinan structural dimana masyarakat terlebih perempuan kehilangan sumber-sumber kehidupan dan sumber mata pencaharian-nya sehingga harus mencasumber penghidupan ke luar negeri sebagai sebuah strategi bertahan hidup. Dalam situasi pemiskinan, perempuan dan laki-laki mengalami dampak namun dampak yang dirasakan perempuan sangatlah berbeda dan berlipat ganda. Hal ini diakibatkan oleh kontruksi jender maupun control dan penindasan seksualitas yang dialami perempuan. Berbagai situasi, perempuan kerap tidak diminta pandangan dan keputusannya atas hidup dan sumber kehidupannya. Dalam berbagai situasi tersebut akhirnya perempuan mencari nafkah keluarga dengan bekerja keluar negeri. Rumusan Permasalahan yang ada yaitu Bagaimana gambaran pengalaman kerentanan yang dialami Perempuan purna Pekerja Migran Indonesia dan Bagaimana Dampak Psikologis Pengalaman Kerentanan yang dialami Perempuan purna Pekerja Migran Indonesia?

\section{Metode Penelitian}

\section{Partisipan}

Penelitian Kualitatif ini menggunakan pendekatan Studi kasus, Hanurawan (2016). Mengemukakan bahwa metode penelitian kualitatif adalah penelitian yang berupaya secara cermat menjawab pertanyaan pertanyaan penelitian melalui pengamatan terhadap latar belakang sosial budaya individu yang tinggal di dalam latar belakang tersebut. Smith (2009) menyatakan mereka yang ingin menyelidiki pengalaman secara detail akan cenderung menoleh metode-metode kualitatif. 
Konsentrasi pada pengalaman manusia sebagai topik sentral psikologi benar-benar tidak dapat dipisahkan dari penelitian kualitatif.

Kriteria partisipan Penelitian adalah purna Pekerja Migran Indonesia yang mengalami berbagai situasi kerentanan saat bermigrasi. Penulis memilih subjek penelitian berdasarkan pada kasusnya. Pada penelitian ini, peneliti hanya meminta kesediaan empat orang yang pernah bermigrasi dan menjalani masa kerja di Negara tujuan dari kelompok Perempuan mantan buruh migran di Kelurahan Bangkala Kecamatan Manggala Kota Makassar untuk menjadi subjek penelitian. Identitas partisipan dapat dilihat secara rinci pada tabel 1. Demi menjaga kerahasiaan identitas partisipan, peneliti mencantumkan nama samaran.

Tabel 1 Identitas Partisipan Penelitian

\begin{tabular}{|l|l|l|l|l|}
\hline $\begin{array}{c}\text { Partisipan } \\
\text { (samaran) }\end{array}$ & Usia & Pendidikan & $\begin{array}{c}\text { Usia saat mengalami situasi } \\
\text { Kerentanan masa kerja } \\
\text { sebagai PMI }\end{array}$ & $\begin{array}{c}\text { Lamanya menjadi } \\
\text { PMI }\end{array}$ \\
\hline $\mathrm{A}$ & 41 tahun & SMK & 25 tahun & 6 Tahun \\
\hline $\mathrm{S}$ & 51 tahun & SMP & 36 tahun & 15 Tahun \\
\hline $\mathrm{Si}$ & 23 tahun & SMK kelas 1 & 8 tahun & 13 Tahun \\
\hline
\end{tabular}

\section{Metode Pengumpulan Data}

Penelitian ini dilakukan dengan menggunakan metode observasi dan wawancara mendalam. Pengumpulan data peneliti dibantu oleh Solidaritas Perempuan Anging Mammiri salah satu organisasi perempuan di Sulawesi Selatan yang berada di Kota Makassar dan bergerak pada isu perlindungan perempuan buruh migran dan trafficking. Hal ini karena keberadaan perempuan buruh migran di Makassar sulit di Identifikasi sehingga melalui Solidaritas Perempuan Anging Mammiri yang focus mendampingi dan melakukan penguatan ke perempuan mantan buruh migran memudahkan peneliti untuk melakukan proses wawancara dan observasi langsung. Sebelum dilakukan wawancara, peneliti menjelaskan tujuan penelitian dan menanyakan kesediaan perempuan mantan buruh migran untuk menjadi partisipan. Peneliti memberikan informed consent untuk di tanda tangani.

\section{Teknik Analisis Data}

Analisis data yang digunakan dalam penelitian ini adalah teknik analisis dengan menyiapkan dan mengorganisasikan data yaitu, data teks seperti transkrip, 
atau data gambar seperti foto) untuk analisis, kemudian mereduksi data tersebut melalui proses pengodean dan peringkasan kode, dan terakhir menyajikan data dalam bentuk bagan, table atau pembahasan (Creswell, 2015). Dengan pendekatan ini, temuan penelitian terdahulu menjadi pedoman bagi peneliti untuk membuat

kodifikasi berdasarkan hasil wawancara. Peneliti juga mengeksplorasi tema atau kategori lain apabila ditemukan jawaban diluar temuan sebelumnya. Proses pengodean dimulai dengan melakukan pengodean terbuka. Kode terbuka dilakukan untuk menentukan pengalaman hidup yang dialami oleh masing-masing partisipan. Setelah itu, peneliti mencoba untuk mencari tema-tema yang muncul dari transkrip untuk ditetapkan menjadi tema-tema yang menjadi pembahasan pada tahap akhir proses analisis. Peneliti menemukan tema-tema yang berkaitan dengan pengalaman kerentanan yang dialami perempuan purna pekerja migran yang berdampak ke kondisi psikologisnya.

\section{Hasil Penelitian}

Pertanyaan pertama untuk mengungkap proses pengambilan keputusan perempuan mejadi pekerja migran Indonesia adalah "dapatkah anda bias menceritakan tentang bagaimana awal mula bekerja di Malaysia ?" Dari pertanyaan tersebut muncul beberapa kondisi yang dialami oleh perempuan pekerja migran selama masa kerjanya yang berpengaruh terhadap kondisi dinamika psikologisnya. Di bawah ini dipaparkan mengenai proses pengambilan keputusan perempuan menjadi pekerja migran Indonesia dan secara ringkas proses tersebut dapat dilihat pada lampiran verbatim para partisipan.

\section{Gambaran Dinamika Psikologis (Decision Making)menjadi Perempuan PMI}

Beberapa aspek yang menjadi penekanan utama sebagai faktor yang mempengaruhi perempuan dalam mengambil keputusan menjadi PMI merupakan salah satu bentuk dinamika psikologis yaitu disebabkan kerena faktor ekonomi, ketersediaan lapangan kerja, posisi dan peran perempuan.

Aspek ekonomi sebagai awal dari adanya dorongan untuk mengambil keputusan menjadi pekerja migran, terutama bagi mereka yang telah berkeluarga. Kebutuhankebutuhan hidup dasar keluarga perlu pemenuhan namun terhimpit pada persoalan ekonomi. Melihat relasinya dengan latar belakang pendidikan menguatkan temuan 
bahwa perempuan yang memilh menjadi pekerja migran karena akses terhadap pendidikan yang begitu minim sehingga tidak memiliki kapasitas pengetahuan yang mumpuni serta kecakapan skill yang memadai, sehingga perempuan lebih memilih menjadi pekerja migran disektor perkebunan yang mudah dijangkau dan cukup menjanjikan peningkatan perekonomian yang lebih baik.

Selanjutnya aspek ketersediaan lapangan kerja juga menjadi faktor yang penting dalam mendorong keputusan perempuan menjadi PMI. Kurangnya ketersediaan lapangan kerja di Negara asal yang dapat dijangkau menyebabkan perempuan terpaksa mengambil langkah untuk menjadi pekerja di Negara Tujuan dengan skill seadanya. Keadaan ini menyebabkan perempuan bekerja sangat keras untuk mendapatkan pekerjaan hubungannya dalam menunjang perekonomian keluarga.

Aspek lainnya yang tidak kalah pentingnya adalah perihal peran dan posisi perempuan. Selain menjadi seorang istri, juga sebagai seorang ibu yang turut mengambil peran untuk berpikir soal pemenuhan kebutuhan keluarga dengan berusaha untuk tetap mendapatkan kesempatan kerja.

\section{Gambaran Situasi Kerentanan yang dialami}

Beberapa aspek yang menjadi penekanan utama sebagai gambaran situasi pengalaman kerentanan yang dialami perempuan saat menjadi pekerja Migran adalah kekerasan, Jeratan Hutang, Proses menjadi Un-documented, beban kerja.

Kekerasan yang dirasakan oleh perempuan pekerja migran merupakan titik awal dari gambaran Dampak Psikologis Pengalaman Kerentanan yang dialami saat mengalami beragam situasi. kekerasan ini terdapat dalam beragam bentuk diantaranya yaitu kekerasan fisik yang dialami oleh salah satu anggota keluarga karena didasari keadaan terpaksa harus lari dan keluar dari tempat yang menjebak mereka kedalam indikasi pola trafficking, gambaran perasaan yang muncul adalah merasa tidak aman, terintimidasi, terancam, dan pemaksaan.

Kekerasan yang dialami bermula saat semua subjek penelitian telah mengambil keputusan untuk meninggalkan tempat bekerja pertama karena pertimbangan upah yang didapatkan akan lebih besar tanpa pernah tahu resiko-resiko yang akan dihadapi karena tidak memiliki informasi maupun pengalaman sebelumnya terlihat sebagai manifestasi dari motivasi menciptakan kondisi hidup yang lebih baik.

Jeratan hutang sebagai salah satu bentuk kerentanan yang dialami para perempuan pekerja migran saat berada dalam pola kerja indikasi trafficking. sumber 
daya yang dibutuhkan dan harusnya menjadi hak sebagai pekerja baik berupa materil dan imateril dirampas. Gambaran jeratan Hutang terkait dengan kondisi structural yang terjadi akibat ketimpangan relasi kuasa antara pemberi kerja dengan pekerja/buruh sehingga sangat menyulitkan perempuan pekerja migran keluar dari situasi tersebut. Situasi ini tentu menerangkan buruknya perlakuan yang didapatkan sehingga berdampak ke kondisi tekanan mental perempuan pekerja migran.

Aspek lainnya pada gambaran proses menjadi undocumented yang merujuk pada pola bersama saat meninggalkan tempat kerja pertama dimana dokumen seperti passport yang dimiliki berada ditangan pemberi kerja awal. interaksi yang terjadi selama proses kerja ini memberikan ruang bagi para pekerja migran untuk mudah terbawa dan terjebak dalam pengaruh iming-iming sehingga tidak memikirkan lebih jauh resiko kerentanan yang akan dialami sehingga dengan adanya situasi yang membuat perempuan pekerja migran menjadi tidak berdokumen membawanya pada berbagai kondisi yang lebih rentan.

Hal yang berbeda dengan beban kerja yang mengarah pada kondisi suatu pekerjaan yang dirasakan diluar kemampuan. Terjadinya bentuk eksploitasi fisik dan emosional selama menjadi pekerja/buruh. Jam kerja yang berlebihan, tidak diupah, ekspoitasi kerja usia anak. Situasi ini tercipta dengan adanya relasi kuasa yang lebih mendominasi. Konteks ini diartikan sebagai kondisi psikologis yang kompleks. Jam kerja yang berlebihan dan tidak mendapatkan upah yang layak serta anak diposisikan sebagai pihak yang secara psikologis belum dapat di tempatkan sebagai pekerja. Situasi ini sebagai manifestasi dari terciptanya perasaan negatif saat bekerja.

\section{Kondisi psikologis Perempuan purna PMI}

Beberapa aspek yang menjadi penekanan utama pada gambaran dampak psikologis sebagai individu perempuan pekerja migran adalah gambaran trauma, gangguan kecemasan dan gangguan emosi.

Pada gambaran trauma, hal yang dikemukakan oleh subjek penelitian sebagai refleksi dari peristiwa yang dialami adalah kondisi yang menjadi pengalaman traumatis individu yang terkait dengan atribut-atribut tertentu saat berada di lingkungan sosial masyarakat. Hal ini dapat dikatakan bahwa semua pengalaman traumatis dapat direpresentasikan saat mengulang atau mengingat kembali peristiwa yang dialami dan menimbulkan respon emosional. 
Gambaran kondisi psikologis selanjutnya yaitu gangguan kecemasan dan gangguan emosional. Terbagi atas dua dimensi yaitu dimensi diri positif dan dimensi diri negatif. Dua dimensi gambaran diri ini membentuk kemampuan interaksi dan terdapat harapan-harapan individu di dalamnya. Pada gambaran kondisi psikologis sebagai individu, dimensi gambaran tersebut menentukan kemampuan interaksi seseorang. Ke-mampuan interaksi ini ditentukan oleh sikap yang dimiliki oleh individu. Sikap di sini adalah hal-hal yang disukai dan tidak disukai oleh individu serta berkaitan dengan apa yang diharapkan orang lain bertindak kepadanya dan apa yang diharapkan oleh dirinya bertindak kepada orang lain. Selain itu, nilainilai yang diyakini oleh individu termasuk dalam sikap individu. Sehingga sikap merupakan pembentuk kemampuan interaksi individu.

Selanjutnya, dari dua dimensi tersebut terdapat harapan-harapan individu di dalamnya. Harapan-harapan yang terkait dengan apa yang diinginkan seseorang dalam kehidupannya. Seperti keinginan yang terkait dengan rasa aman, keinginan yang terkait dengan berkumpul dengan keluarga, dan keinginan yang terkait dengan bebas dari tekanan yang ada. Harapan-harapan ini juga dibentuk oleh sikap- sikap pada individu. Sehingga, harapan-harapan yang muncul dalam diri individu dibentuk oleh apa yang pendirian individu pada suatu kejadian, kondisi, dan orang lain yang ada disekitarnya.

Sikap yang membentuk kemampuan interaksi dan harapan individu ditentukan oleh gambaran kondisi psikologis seseorang. dimensi gambaran tersebut menentukan apa yang akan menjadi sikap dan pengharapan seseorang. Hal ini dibentuk berdasarkan akumulasi pengalaman dalam hidup, pengalaman dalam berinteraksi dengan orang lain, dan pengalaman kerentanan yang dimiliki.

Berdasarkan pemaparan di atas maka dapat ditarik sebuah kesimpulan bahwa, gambaran dari dampak Psikologis Perempuan purna Pekerja Migran Indonesia sebagai individu adalah penentu untuk menjadi lebih berdaya secara psikologis atau semakin terpuruk karena pengalaman kerentanan yang dialami.

\section{Diskusi}

Pola migrasi yang dilakukan perempuan di Kelurahan Bangkala Kecamatan Manggala kota Makassar dapat dilihat dari gambaran pengambilan keputusan saat akan memilih menjadi pekerja migran yang tentu sangat berelasi dengan sistem stuktural sebagai faktor pendorong terjadinya fenomena feminisasi migrasi. 
Pemiskinan stuktural yang disebabkan oleh skema alih fungsi lahan pertanian menjadi pemukiman padat penduduk serta tidak adanya lapangan kerja menjadi alasan sebagian besar perempuan di Kelurahan Bangkala Kecamatan Manggala menjadi pekerja migran disektor perkebunan di Negara tujuan.

Minimnya informasi soal mekanisme migrasi, perlindungan dan resiko-resiko menjadi pekerja migran serta kebijakan yang berlaku di negara tujuan menjadikan perempuan sangat rentan. kerentanan yang dialami pun menjadi pola migrasi yang sangat kompleks dirasakan perempuan pekerja migran mulai dari berbagai bentuk kekerasan, jeratan hutang, proses menjadi tidak berdokumen, dan beban kerja yang tentu dapat diindikasikan sebagai pola trafficking.

Gambaran kondisi dampak psikologis perempuan purna pekerja migran pun menjadi dasar pertimbangan dari hasil temuan penelitian ini antara lain trauma, gangguan emosi dan gangguan kecemasan sebagai aspek kondisi psikologis dari pengalaman kerentanan yang pernah dialami.

Ciri dari gambaran dinamika psikologis yaitu saat perempuan mengambil keputusan menjadi pekerja migran cenderung karena keadaan social ekonomi rumah tangga migran hasil penelitian Utami \& Sukamdi (2012) mengungkapkan bahwa yang menjadi faktor pendorong pekerja migran perempuan di Desa Jangkaran bekerja diluar negeri yaitu faktor pendorong didaerah asal seperti terdesak akan kebutuhan ekonomi serta tidak terdapat lapangan kerja. selain itu informasi bekerja di luar negeri juga mempengaruhi pengambilan keputusan migran perempuan bermigrasi ke luar negeri, baik informasi dari migran kembali, lembaga pemerintah yang terkait maupun sponsor. Hendaknya migran memutuskan bermigrasi ke luar negeri dengan mempertimbangkan resiko yang mungkin terjadi dengan menggali informasi selengkap-lengkapnya mengenai proses migrasi ke luar negeri untuk bekerja yang diperoleh tidak hanya dari migran kembali dan sponsor tetapi juga dari lembaga-lembaga pemerintah terkait.

Situasi kerentanan perempuan pekerja migran dialami hampir di seluruh tahapan migrasi. Melihat system perburuhan di Indonesia sangatlah rentan dari praktek perbudakan terselubung baik di dalam negeri ataupun diluar negeri. UU No. 18 Tahun 2017 tentang perlindungan pekerja migran Indonesia sebagai peraturan tertinggi dalam menangani masalah buruh migran tidak memasukkan definisi mengenai buruh migran yang tidak berdokumen. UU tersebut tentunya masih belum berperspektif perlindungan karena hingga saat ini belum ada aturan turunan yang memperkuat keberadaan regulasi tersebut. 
Undocumented dan documented terkait dengan perkembangan krisis global yang kian akut memicu beberapa Negara penerima salah satunya Malaysia. Krisis ekonomi mendorong Negara penerima meningkatkan kebutuhan buruh migran Indonesia yang tidak berdokumen agar tidak punya hak untuk melakukan apapun dan untuk mendapatkan tanaga buruh murah. Di Negara pengirim seperti Indonesia, banyak yang memilih untuk menjadi pekerja migran yang tidak berdokumen karena keterpaksaan agar tidak dibebani pungutan biaya yang mahal dari proses pemerangkatan ketika menjadi pekerja migran. Hidayati (2013) menjelaskan Permasalahan utama buruh migran Indonesia di luar negeri yaitu pola hubungan kerja antara buruh migran dan majikannya masih dibangun secara sepihak oleh majikan tanpa memperhatikan hak dan suara buruh. buruh migran rata-rata belum mengikuti standar upah negara setempat dan belum mendapatkan hak-hak yang sama dengan buruh/pekerja di negara tersebut, ketika terjadi konflik dengan majikan, rata-rata buruh migran belum memiliki kekuatan untuk menyelesaikannya secara hukum melalui pengadilan atau mediasi pihak ketiga. Meskipun buruh migran memberikan kontribusi penting terhadap pembangunan ekonomi lokal, perhatian terhadap perbaikan perlindungan baik di dalam negeri maupun di luar negeri masih belum memadai.

Anandari dkk (2018) menjelaskan bahwa dampak trafficking di Desa Nomporejo, Galur, Kulon Progo, Yogyakarta yaitu timbulnya, Timbulnya Rasa Takut dan Cemas yang Menetap pada korban trafficking, Munculnya kasus perceraian di dalam rumah tangga koban trafficking, Dan munculnya pengaruh buruk terhadap perkembangan pendidikan anak. Dalam pelaksanaan penempatan TKI/TKW yang rentan terjadinya kasus Trafficking, kondisi keluarga (keadaan rumah tangga).

Kaplan, H.I., Sadock, B. J., Grebb, J. A. (1997) menjelaskan bahwa PTSD (Post Trauma Syndrom Disorder) merupakan sindrom kecemasan, labilitas sutonomis, ketidakmampuan emosional dan kilas balik dari pengalaman yang amat pedih itu setelah stress fisik maupun emosi yang melampaui batas ketahanan orang biasa. Hikmat (2005) menyebutkan PTSD sebagai sebuah kondisi yang muncul setelah pengalaman luar biasa yang mencekam, mengerikan dan meng-ancam jiwa seseorang (Fuadi, 2011).

Minimnya pengetahuan dan informasi akibat dari resiko terjadinya kasusTrafficking Dampak trafficking di Desa Nomporejo, Galur, Kulon Progo, Yogyakarta meliputi Timbulnya Rasa Takut dan Cemas yang Menetap pada korban trafficking kondisi ini muncul di-karenakan adanya dampak psikis yang 
dialami oleh korban Trafficking yang meng-alami kasus trafficking berat seperti kekerasan fisik, pelecehan seksual dan penganiayaan psikis dan mental. Timbulnya rasa takut dan cemas yang berlebihan biasanya dapat mengakibatkan gangguan kejiwaan atau mental.

Islam et al., 2010; Tsai, 2012; Naing et al., (2012) menjelaskan Masalah kesehatan jiwa pada pekerja migran di luar negeri terus mengalami peningkatan. Hal ini diakibatkan karena kerentanan para pekerja migran terhadap masalah hukum, kekerasan fisik, sosial ataupun psikis. Banyak pekerja migran di luar negeri berada dalam situasi lingkungan kerja yang kurang aman, lingkungan perumahan yang minim sanitasi, rumah tak layak huni, kurangnya akses ke pelayanan kesehatan dan mengalami berbagai perlakuan kekerasan selama menjalankan pekerjaan (Darthayasa, dkk. 2016).

Stuart (2015) menjelaskan permasalahan fisik atau trauma pada fisik dan permasalahan psikis mempunyai korelasi dengan kecenderungan individu mengalami permasalahan jiwa. Permasalahan ini bisa menjadi salah satu faktor predisposisi ataupun presipitasi terjadinya masalah jiwa. Respon dalam bentuk perasaan dalam pandangan kesehatan jiwa merupakan bagian dari penilaian individu terhadap stresor yang dialami. Penilaian ini menjadi jawaban atau tanggapan terhadap stimulus yang muncul. Penilaian tersebut bisa bermacammacam tergantung stresor yang datang dan memunculkan suatu mekanisme koping dalam menghadapi permasalahan. Mekanisme koping yang muncul dapat berupa mekanisme koping yang bersifat konstruktif maupun destruktif. Mekanisme yang bersifat konstruktif berkaitan dengan kemampuan penyesuaian dan kemampuan penyelesaian masalah, sementara mekanisme destruktif cenderung lebih bersifat negatif dan menghindari resolusi. Acosta \& Acosta (2013) Menjelaskan Keluhan fisik dan psikis dalam abuse ini merupakan dua hal sebab akibat yang efeknya berujung pada masalah kesehatan jiwa yang lebih serius lagi.

\section{Kesimpulan}

Salah satu faktor dinamika psikologi perempuan yaitu pengambilan keputusan, perempuan memutuskan untuk menjadi pekerja migran karena dilatarbelaktangi oleh faktor ekonomi, tidak tersedianya peluang kerja dan sebagai bentuk usaha dalam mengharapkan kehidupan yang lebih baik dan sejahtera. Peran dan posisi perempuan. Selain menjadi seorang istri, juga sebagai seorang ibu yang turut 
mengambil peran untuk berpikir soal pemenuhan kebutuhan keluarga dengan berusaha untuk tetap mendapatkan kesempatan kerja.

Situasi kerentanan yang dialami yaitu saat berada di Negara tujuan yang dipengaruhi oleh faktor minimnya informasi atau pengetahuan soal kebijakan migrasi di Negara tujuan dan resiko-resiko kerja ketika tidak berdokumen. Interaksi yang terjadi selama proses kerja ini memberikan ruang bagi para pekerja migran untuk mudah terbawa dan terjebak dalam pengaruh iming-iming sehingga tidak memikirkan lebih jauh resiko kerentanan yang akan dialami sehingga dengan adanya situasi yang membuat perempuan pekerja migran menjadi tidak berdokumen membawanya pada berbagai kondisi yang lebih rentan. Situasi pengalaman kerentanan yang dialami disebabkan oleh iming-iming upah yang lebih besar sehingga terjebak dalam pola indikasi trafficking diantaranya mengalami kekerasan fisik maupun psikis seperti intimidasi, ancaman dan pemaksaan, kemudian jeratan hutang yang mengakibatkan perempuan tidak nyaman dan menikmati pekerjaannya dan tetap berusaha sebagai upaya keluar dari jeratan hutang. Beban kerja berat yang dialami seperti overtime, tidak diupah dan eksploitasi kerja usia anak. Dampak psikologis yang dialami perempuan purna pekerja migran yaitu Trauma, Gangguan Emosi dan Gangguan Kecemasan. Dari dampak Psikologis Pengalaman Kerentanan yang dialami perempuan purna pekerja migran Indonesia di Kelurahan Bangkala kota Makassar antara lain melakukan upaya untuk kuat bertahan dan berusaha mencari jalan keluar dari situasi pola traffincking dengan berbagai kerentanan yang dialami.

\section{Daftar Pustaka}

Abraham P. F. (2014). Social Work in Mental Health. Sage Publications: New Delhi Acosta, I. C \& Acosta, A. S. (2013). In Pain and In Wail: A Phenomenology of The Abuse of The Filipino Domestic Workers. Qatar. WIEGO.

Anandari, Y. A., Sekarini, O., \& Widiastuti, A. (2018). Keadaan Sosiologis Mantan Buruh Migran Korban Trafficking Di Desa Nomporejo Galur Kulon Progo Yogyakarta. Jipsindo, 5(1), 44-60.

Suwetty, A. M., Astari, A. M., \& Wihastuti, T. A. (2019). Mental Health of Human trafficking; A Systematic Review. Research Journal of Life Science, 6(2), 130140 .

Bhugra Dinesh. (2004). Migration and mental health. Institute of Psychiatry, London. March -https://doi.org/10.1046/j.0001-690X.2003.00246.x 
Chaplin, J.P. (2006) Kamus Lengkap Psikologi (Penerjemah Kartini Kartono), (Jakarta: Raja Gravindo Persada), Hlm. 78

Creswell, W., John. (2015). Penelitian Kualitatif dan Desain Riset. Yogyakarta: Pustaka Pelajar

Dinesh Bhugra \& Susham Gupta. (2011). Migration and Mental Health. Cambridge University Press : UK

Desintha Dwi Asriani \& Ezka Amalia. (2014). Jejak Perempuan Buruh Migran dalam Masyarakat ASEAN 2015. Jurnal Ilmu Sosial dan Ilmu Politik, Volume 18, Nomor 2, November

Darthayasa, I Nengah., Indah Winarni.,Retno Lestari. (2016).Pengalaman Tenaga Kerja Indonesia (TKI) yang mengalami Abuse. Jurnal Ilmu Keperawatan Volume 4, No. 2.

Fathorrochman, \& Djalaludin Ancok. (2012). Dinamika Psikologis Penilaian Keadilan. (Jurnal Psikologi Ugm) 1, Hlm. 41-60

Fuadi, Anwar M. (2011). Psikoislamika, Jurnal Psikologi Islam. Dinamika Psikologis Kekerasan Seksual: Sebuah Studi Fenomenologi. Lembaga Peneliian Pengembangan Psikologi dan Keislmanan. Vol 8 No.2, 191-208.

Hanurawan, Fattah. 2016. Metode Penelitian Kualitatif untuk Ilmu Psikologi. Jakarta: Jajawali Pers.

Herdiana, I., Kanthi, S. R., \& Suryanto, S. (2019). 'Girls Trade' : Portrayal of the Psychosocial Problems of Human Trafficking Survivor. North American Journal of Psychology, 21(1), 125-126

Hidayati Nur. (2013) Perlindungan Hukum terhadap Buruh Migran Indonesia. Jurnal Pengembangan Humaniora Vol. 13 No. 3.

I Nengah Darthayasa, Indah Winarni, Retno Lestari. Pengalaman Tenaga Kerja Indonesia (TKI) yang mengalami Abuse. Jurnal Ilmu Keperawatan - Volume 4, No. 2 November 2016.

Maulidia, A. A. (2019). The Obstacles In Fulfilling Social Protection For Indonesian Women Migrant Workers In Malaysia From 2016 To 2018. Jurnal Hubungan Internasional Vol. 8, No. 2 / October 2019 - March 2020

Ramdhany, D. R. (2016). Responsibility of Protection Indonesian Female Migrant Workers. International Journal of Business, Economics and Law, 10(4).

R. Saptoto. (2009). Jurnal Psikologi Indonesia. (Dinamika Psikologis Nerimo Dalam Bekerja: Nerimo Sebagai Motivator Atau Demotivator), 2 (6), Hlm. 131-137. 
S. D. Holloway, S. Suzuki, Y. Yamamoto, \& J. D. Mindrich, Relation Of Maternal Role Concept To Parenting, Employment Choices, And Life Satisfaction Among Japanese Women (Sex Roles, 2006) 54, Hlm. 235-249

Smith, Jonathan. A. 2008. Psikologi Kualitatif Panduan Praktis Metode Riset. Yogyakarta: Pustaka Pelajar

Sukamdi. Memahami Migrasi Pekerja Indonesia ke Luar Negeri. (2007). Populasi, 18(2), ISSN: 0853-0262

Stuart, G. W. (2015). Prinsip dan praktik keperawatan kesehatan jiwa Stuart. Edisi Indonesia. Alih bahasa oleh: Keliat, B. A. Elsevier.

Utami, Rizqika T., \& Sukamdi Sukamdi. (2012). "Pengambilan Keputusan Bermigrasi Pekerja Migran Perempuan (Kasus Di Desa Jangkaran, Kecamatan Temon Kabupaten Kulon Progo)." Jurnal Bumi Indonesia, vol. 1, no. 1.

Widiasari. Y. (2009). Dinamika Psikologis Pencapaian Succesful Aging Pada Lansia Yang Mengikuti Program Yantu Lansia, Tesis (Tidak Diterbitkan), (Yogyakarta: Fakultas Psikologi Ugm). 